\title{
SONARAVNA ZASNOVA REGIONALNEGA RAZVOJA SLOVENIJE
}

\author{
Plut Dušan \\ Oddelek za geografijo, Filozofska fakulteta Univerze v Ljubljani, \\ Aškerčeva 2, SI-I000 Ljubljana \\ e-mail: plutl@telemach.net \\ Izvirni znanstveni članek \\ COBISS 1.01
}

\section{Izvleček}

Glede na majhno velikost ozemlja so regionalne razlike v Sloveniji dokaj izrazite, negativne posledice pa se kažejo tudi na okoljskem polju. Dvig materialnega blagostanja je bil zlasti v nekaterih regijah dosežen tudi na račun izčrpavanja naravnih virov in obremenjevanja geografskega okolja. Slovenija lahko sonaravne značilnosti in razsežnosti lastne in evropske prostorske in regionalne zasnove udejanja z razmeščanjem temeljnih prostorskih in regionalnih struktur v okviru različnih regionalnih zmogljivosti geografskega okolja.

Ključne besede: sonaravni regionalni razvoj, ekologizacija gospodarstva, naravni viri, Slovenija

\section{SUSTAINABLE PLAN FOR REGIONAL DEVELOPMENT OF SLOVENIA}

\begin{abstract}
In view of the small size of its territory, regional differences are quite explicit in Slovenia, and negative effects are also evident in the environmental sphere. The rise of material welfare, especially in certain regions, was reached at the cost of exhausting natural resources and polluting the geographical environment. Slovenia can effectuate sustainable characteristics and the dimensions of its own and of the European spatial and regional scheme by distributing the elementary spatial and regional structures within the scope of different regional capacities of the geographical environment.
\end{abstract}

Key words: sustainable regional development; ecologization of economy; natural resources; Slovenia 


\section{ORIS (NE)SONARAVNIH SESTAVIN PRETEKLEGA REGIONALNEGA RAZVOJA SLOVENIJE}

Razlike v naravnih razmerah ter v historičnem in socialnogospodarskem razvoju slovenskih regij so po mnenju Vrišerja (1998) poglavitni vzrok za regionalno razvojne probleme, ki se zaostrujejo tudi po osamosvojitvi. Glede na majhno velikost ozemlja so regionalne razlike v Sloveniji dokaj izrazite, negativne posledice pa se kažejo tudi na okoljskem polju. Pritiski na prostor in okolje so najmočnejši na obrobju večjih mest in zaposlitvenih središč, območjih ob priključkih na pomembnejše prometne koridorje, v pokrajinsko privlačnih območjih in obalnem pasu (Strategija prostorskega razvoja Slovenije, 2004). Okoljsko negativne posledice neuravnoteženega regionalnega razvoja so skupna pokrajinska rezultanta prekomerne zgostitve prebivalstva in dejavnosti $\mathrm{v}$ geografskih območjih s skromnimi samočistilnimi zmogljivostmi. Vendar Slovenijo hkrati označuje velika prostorska razpršenost manjših naselij in številna naselja z razpršenimi zgradbami, kar vpliva zlasti na intenzivnejšo rabo naravnih virov v različnih območjih in povečanje prometa (Černe, 2004). V robnih in vzpetih območjih Slovenije pa poteka dolgotrajno izseljevanje prebivalstva in zaraščanje kulturne pokrajine.

Posamezni in sintezni kazalci trajnostno sonaravnega regionalnega razvoja kažejo na izrazito delitev Slovenije na dve polovici: pretežno nadpovprečno in pozitivno ocenjene zahodne regije in pretežno podpovprečno (in negativno) ocenjene vzhodne regije (Preglednica 1; Slika 1). Delno odstopanje od navedene splošne slike izkazujejo okoljski kazalci (Vintar, 2003, 151).

Preglednica 1: Rangi statističnih regij Slovenije po BDP in nekaterih sinteznih kazalcih trajnostno sonaravnega regionalnega razvoja (1997-2002)

Table 1: Rang of statistical regions in Slovenia according to GDP and selected indicators of sustainable regional development (1997-2002)

\begin{tabular}{|c|c|c|c|c|c|}
\hline Statistična regija & $\begin{array}{c}\text { BDP na } \\
\text { prebivalca } \\
(2002)\end{array}$ & $\begin{array}{c}\text { Indeks } \\
\text { razvojne } \\
\text { ogroženosti } \\
(2000) \\
\end{array}$ & $\begin{array}{c}\text { Kazalec } \\
\text { TSR } \\
(1997-2002)\end{array}$ & $\begin{array}{c}\text { Stanje okolja } \\
\text { (zrak, voda) } \\
(1999-2000)\end{array}$ & $\begin{array}{c}\text { Razkoraki } \\
\text { med rangom } \\
\text { stanja okolja } \\
\text { (vode+zrak) in } \\
\text { rangom BDP }\end{array}$ \\
\hline 1.Osrednje-slovenska & 1 & 1 & 1 & 10 & -9 \\
\hline 2. Obalno-kraška & 2 & 2 & 4 & 3 & -1 \\
\hline 3. Goriška & 3 & 4 & 3 & 1 & +2 \\
\hline 4. JV Slovenija & 4 & 5 & 5 & 2 & +2 \\
\hline 5. Savinjska & 5 & 8 & 7 & 11 & -6 \\
\hline 6. Gorenjska & 6 & 3 & 2 & 4 & +2 \\
\hline 7. Spodnjeposavska & 7 & 11 & $9-10$ & 8 & -1 \\
\hline 8. Podravska & 8 & 10 & $9-10$ & $6-7$ & $+1,5$ \\
\hline 9. Koroška & 9 & 7 & 8 & $6-7^{*}$ & $+2,5$ \\
\hline 10. Notranjsko-kraška & 10 & 6 & 6 & 5 & +5 \\
\hline 11. Zasavska & 11 & 9 & 11 & 12 & -1 \\
\hline 12. Pomurska & 12 & 12 & 12 & 9 & +3 \\
\hline
\end{tabular}

Vir: SURS, 2004, Vintar, 2003; Agencija za okolje RS, 2002

* ob upoštevanju zastrupljenosti prsti Mežiške doline s težkimi kovinami bi bil rang nižji 


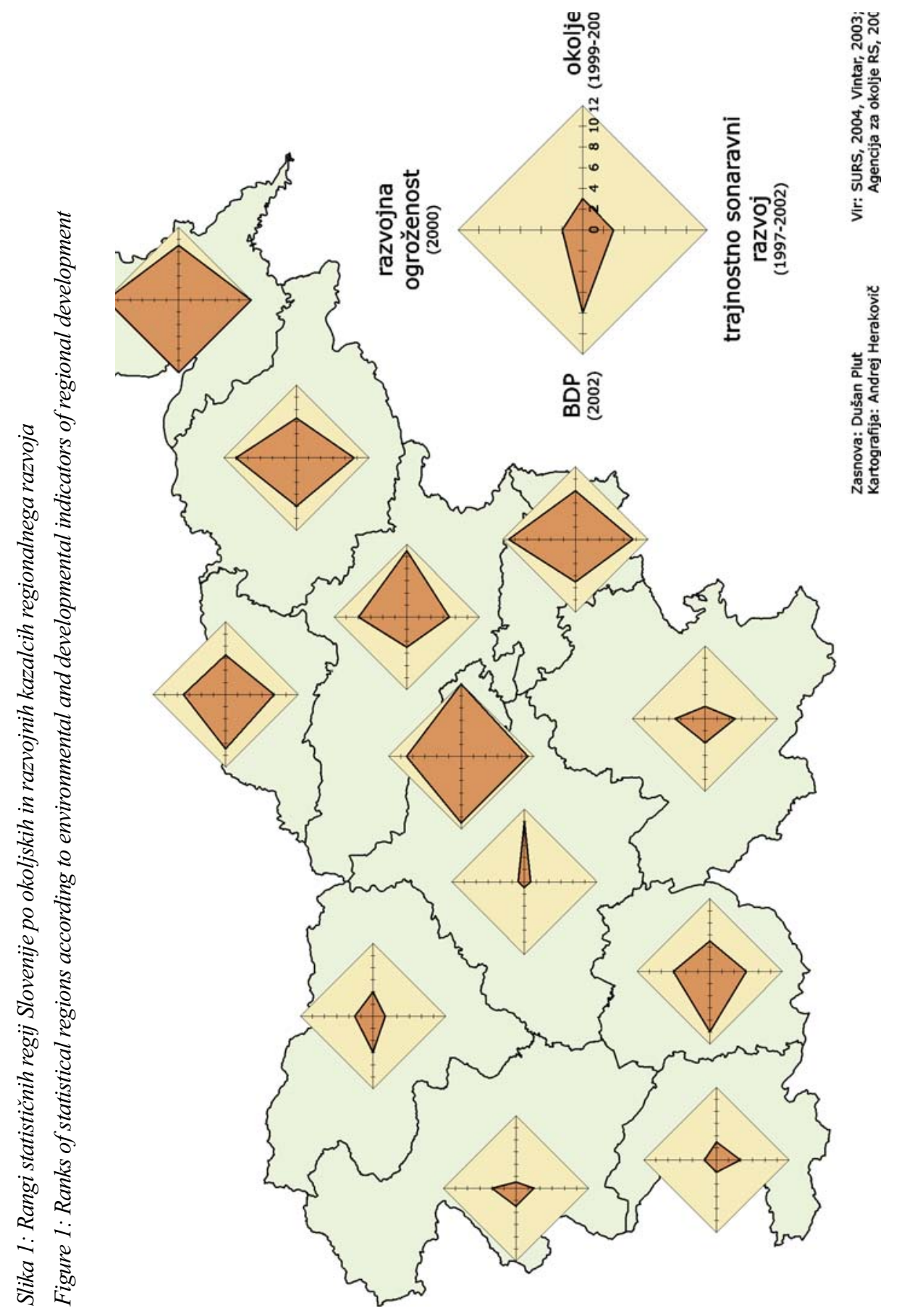


Tipologija statističnih regij z vidika BDP na prebivalca in stanja okolja (zrak, vodni viri) je naslednja (Slika 2):

I: višji BDP (1-6) in višji rang kakovosti okolja (1-6):

1.Goriška (3, 1), 2. Obalno-kraška (2, 3) , 3. JV Slovenija (4, 2), 4. Gorenjska (6, 4);

II. višji rang BDP (1-6) in nižji rang kakovosti okolja (7-12):

5. Osrednjeslovenska $(1,10), 6$. Savinjska $(5,11)$;

III. nižji rang BDP (7-12) in višji rang kakovosti okolja (1-6):

7. Notranjsko-kraška (10, 5), 8. Podravska (8, 6-7);

IV. Nižji rang BDP (7-12) in nižji rang kakovosti okolja (7-12):

9. Spodnjeposavska $(7,8), 10$. Koroška $\left(9,6-7^{*}\right), 11$. Pomurska $(12,9), 12$. Zasavska $(11,12)$.

Slika 2: Tipologija statističnih regij Slovenije z vidika BDP na prebivalca in stanje okolja (zrak, vodni viri) 1999-2002

Figure 2: Typology of statistical regions in Slovenia according to GDP per capita and state of environment (air, water resources) 1999-2002

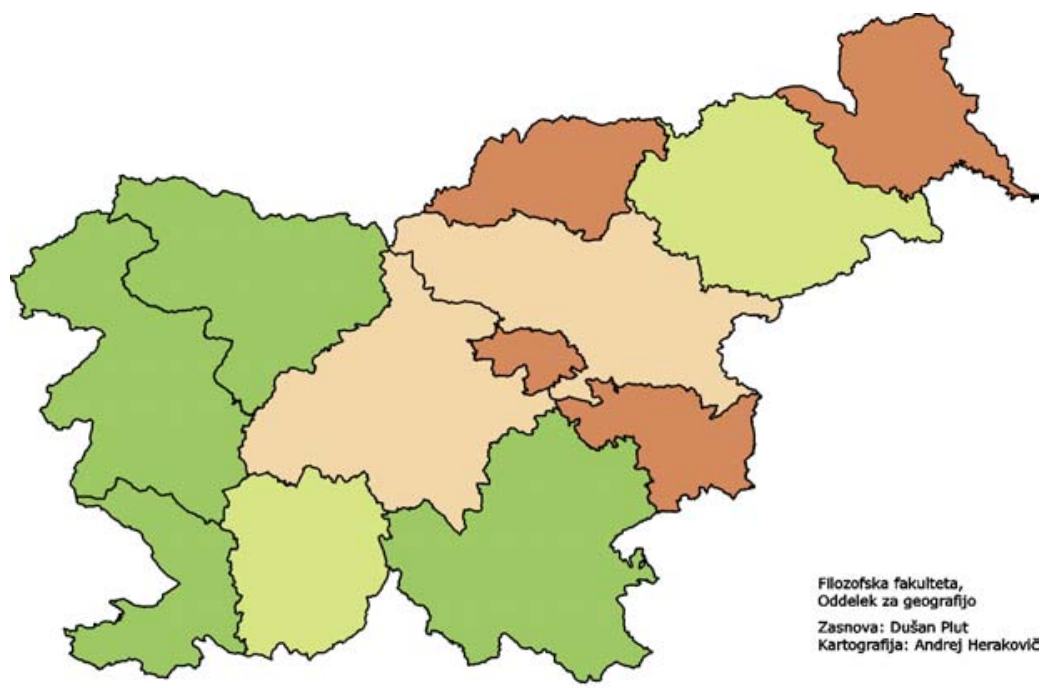

Višji rang BDP (1 - 6) in višji rang kakovosti okolja (1 - 6)

Nižji rang BDP $(7-12)$ in višji rang kakovosti okolja (1 - 6)

Višji rang BDP $(1-6)$ in nižji rang kakovosti okolja (7 - 12)

Nižji rang BDP (7 - 12) in nižji rang kakovosti okolja (7 - 12)

Podatki in ugotovitve kažejo, da je gospodarska rast Slovenije (in zlasti njene najbolj razvite regije-Osrednjeslovenske) bila dosežena tudi na račun okolja in izčrpavanja naravnih virov, nesmotrne rabe prostora, visoke energetske intenzivnosti, kemizacije kmetijstva ter drugih sektorskih, pretežno nesonaravnih politik (Poročilo o okolju, 2005). Zlasti Goriška in Obalno- 
kraška regija pa sta višji BDP na prebivalca dosegli z relativno nižjim onesnaževanjem sestavin okolja. V razvojno-okoljsko najbolj problematičnem položaju pa so statistične regije s skromnim BDP na prebivalca in onesnaženim okoljem, zlasti Zasavje in Pomurje. Navedeni regiji se tudi po sinteznem kazalcu (32 kazalcev) trajnostno sonaravnega razvoja uvrščata na zadnji mesti (Vintar, 2003).

\section{NEKATERE SONARAVNE SESTAVINE REGIONALNEGA RAZVOJA (NAPREDKA) SLOVENIJE}

Med najbolj onesnaženimi slovenskimi kraji in območji so zlasti starejša industrijska središča, ki praviloma ležijo v občutljivih dolinskih in kotlinskih ekosistemih alpske in predalpske Slovenije (Ravbar, Plut, 1999; Špes, 2000). Širša sklenjena območja največje in večplastne pokrajinske degradacije Slovenije (Zasavje, Mežiška dolina, urbano območje Celja, Šaleška dolina in nekatera manjša druga območja in naselja) bi bilo glede na sonaravne usmeritve prostorske in regionalne politike EZ priporočljivo obravnavati kot posebno načrtovalsko prostorsko in razvojno problemsko kategorijo. Kljub prizadevanjem strokovne javnosti v Strategiji regionalnega razvoja (2001) in Strategiji prostorskega razvoja (2004) širša degradirana območja niso bila opredeljena kot problemska območja s svojstvenimi okoljskorazvojnimi problemi. Spodbudno pa je dejstvo, da osnutek Strategije razvoja Slovenije (2004) in Resolucija Nacionalnega programa varstva okolja (2005) območja večplastne degradacije okolja in nekatera manjša okoljsko problematična območja izrecno opredeljujeta kot posebno razvojno-okoljsko sanacijsko območje s poudarjeno okoljevarstveno (preventivno in tudi zelo izrazito kurativno) varovalno zasnovo ukrepov regionalne in prostorske politike. Pozitivno je tudi dejstvo, da v nekaterih degradiranih območjih prihaja do večjega števila okoljskih sanacij degradiranih urbanih površin, kjer se nameščajo nove dejavnosti (Kušar, 2004).

$\mathrm{V}$ regionalnem gospodarstvu in zaposlitvi predstavljajo industrijska podjetja še vedno enega od temeljev, hkrati pa so velik porabnik naravnih virov in vir obremenjevanja okolja. Proces približevanja Slovenije najuspešnejšim državam na področju gospodarske trajnosti terja predvsem strukturne spremembe, zlasti zmanjšanja deleža izdelkov intenzivnih z naravnimi viri (Stanovnik in Ekar Slabe, 2004). Do konca leta 2007 bodo morale industrijske naprave in obrati, ki lahko povzročijo onesnaževanje večjega obsega, pridobiti okoljevarstvena dovoljenja. Zaradi policentrične prostorske zasnove slovenske industrije je pozitivno tudi dejstvo, da se v vseh statističnih regijah Slovenije povečuje število okoljsko bolj odgovornih podjetij, ki udejanjajo program uvajanja najboljših razpoložljivih tehnologij (BAT) in se prostovoljno odločajo za sprejetje sistemov ravnanja z okoljem. Po mnenju Vrišerja $(1998,427)$ naj bi tudi v prihodnje v surovinsko revni Sloveniji industrija zagotavljala razvoj, vendar bo morala upoštevati občutljivo naravno okolje in plačevati stroške za uničeno okolje.

V Sloveniji je bilo po podatkih Gospodarske zbornice Slovenije leta 2001182 podjetij z okoljskim certifikatom ISO 14001, prvi pa je bil podeljen šele leta 1996 . V letu 2002 je bilo podeljenih 36, v letu 2003 pa še 46 certifikatov ISO 14001, temeljni razlog pa je po anketi povečanje konkurenčnosti na tujih trgih, torej v določenem pomenu tudi ekonomska nuja za 
izvoz na okoljsko zahtevnejše trge. Zato je razumljivo, da je leta 200422 od 30 največjih slovenskih izvoznikov imelo okoljski certifikat ISO 14 001. Po številu okoljskih certifikatov na število zaposlenih $v$ industriji in številu podjetij izstopa Obalno-kraška regija, ki sicer po dodani vrednosti na zaposlenega v industriji zaostaja za Osrednjeslovensko regijo. Vendar je potrebno podčrtati, da v letu 2004 na ravni 12 statističnih regij Slovenije še ni obstojala visoka stopnja povezanosti med številom certifikatov na 10000 zaposlenih in dodano vrednostjo na zaposlenega $\mathrm{v}$ industrijskih podjetjih (Hočevar, 2005). Hkrati v zadnjih letih ponovno narašča skupni obseg proizvodnje ti. »umazanih« industrij, ki se po intenzivnosti emisij na enoto proizvoda najvišje rangirajo. Ob hkratni rasti dodane vrednosti »umazanih« industrij pa se njihove investicije v varstvo okolja zmanjšujejo (Poročilo o razvoju 2005). Povečanje podjetij z ISO 14001, nadgradnja standarda ISO 14001 z vpeljavo sistema EMAS in pridobitev znaka za okolje za izdelke so prioritetne okoljske naloge podjetij po vstopu Slovenije v EZ.

Tudi leta 2001 sprejeti Slovenski kmetijsko okoljski program (2001-2006) postavlja v ospredje potrebam potrošnikov prilagojeno, sonaravno kmetijsko pridelavo, ki bo varovala njihovo zdravje, zagotavljala trajno rabo naravnih virov in omogočala ohranjanje biotske raznovrstnosti ter značilnosti slovenskih pokrajin. Čeprav je še vedno poudarjen tudi pomen količinske pridelave hrane, program le omogoča in finančno podpira zmanjševanje okoljskih pritiskov kmetijstva, ohranjanje rodovitnosti prsti, poseljenosti in postopno ekologizacijo kmetijske pridelave. Veliko oviro k (glede na pokrajinsko občutljivost območij intenzivne pridelave hrane) $\mathrm{k}$ oblikam sonaravnega kmetijstva (ekološka in integralna pridelava hrane) predstavlja desetletja podprta usmeritev kmetij npr. v prekomerno rabo mineralnih gnojil in zaščitnih sredstev, tudi na vodovarstvenih območjih talne vode (SV Slovenija).

Delež ekološko obdelanih zemljišč leta 1998 je bil nizek (pod $1 \%$ ), do leta 2003 pa se je v okviru 1400 ekoloških kmetij s 20.000 ha povzpel na 4,1 \% kmetijskih zemljǐ̌̌ v uporabi. Ob takšnem povečevanju je realno pričakovati, da bomo do leta 2010 lahko dosegli 10 \% ekološko obdelanih kmetijskih zemljišč ali vsaj podvojitev trenutnih ekološko obdelanih površin. Ekološka in integralna predelava hrane ohranja tradicionalne kmetijske ekosisteme in kulturno pokrajino, zato je z vidika ohranjanja pokrajinske in biotske raznovrstnosti glede na intenzivno kmetijsko pridelavo pozitiven ukrep. Glede na delež državnih in sredstev kmetijstvu v zadnjih letih v primerjavi z drugimi dejavnostmi (npr. industrijo) pa je proces ekologizacije slovenskega kmetijstva (ekosocialna usmeritev) kot državnega strateškega cilja preskromen. Naravnogeografske (reliefna energija, kraški svet, poplavna območja) in vodnoekološke omejitve (občutljivost zaledja zajetih kraških izvirov in območij talne vode), ohranjanje biotske raznovrstnosti in ekosistemskih storitev, pričakovane posledice podnebnih sprememb (dodatni pritiski na vodne vode $\mathrm{v}$ sušnejših regijah) ter večja evropska in domača tržna niša prodaje okoljsko skrbno pridelane hrane so ključni razlogi za pospešeno sonaravno usmeritev slovenskega kmetijstva $\mathrm{v}$ vseh regijah. Sodimo, da bo udejanjanje sonaravnega načina kmetijske obdelave najtežje doseči v ravninskih območjih talne vode, ki so regionalno strateško pomembna za oskrbo s pitno vodo in hkrati kmetijsko najbolj rodovitna območja. Desetletja se je namreč kmete z različnimi državnimi podporami spodbujalo $\mathrm{k}$ intenzifikaciji in kemizaciji kmetijske proizvodnje, zato bo sicer nujen prehod na vodnoekološko sprejemljive oblike kmetovanja zelo težaven. Zato predlagamo, da se v prihodnje razen razdeljevanja 
sredstev (neposredna plačila) bistveno večja sredstva namenijo namenskemu financiranju npr. okoljsko zasnovanih razvojnih kmetijskih programov npr. v vodovarstvenih območjih regionalnega pomena. Del potrebnih sredstev ekstenzifikacije kmetijstva na vodovarstvenih območij pa bo potrebno (vsaj v fazi prehoda npr. na ekološko pridelavo hrane) zbrati s pomočjo višje cene pitne vode.

Sonaravno zasnovana regionalna politika poudarja izjemno vlogo endogenih naravnih virov oziroma ti. okoljskega kapitala (neobnovljivi in obnovljivi naravni viri, prostor, pejsaž, biotska raznovrstnost in ekosistemske storitve). Zaradi izjemne geografske raznovrstnosti in s tem povezane pokrajinske mozaičnosti ter geološke mladosti ozemlja razpolaga Slovenija in njene regije $\mathrm{z}$ omejenimi, skromnimi zalogami neobnovljivih virov (zlasti fosilnih goriv), raznovrstnimi obnovljivimi viri ter večplastnimi ekosistemskimi storitvami in regionalno zelo različnimi samočistilnimi zmogljivostmi.

Prostorska razpoložljivost ključnih naravnih virov kaže, da so v regijah Slovenije prisotne različne skupine naravnih virov, kar ocenjujemo kot strateško konkurenčno prednost Slovenije in pomemben dejavnik skladnejšega regionalnega razvoja in kakovosti življenja. Policentrični razvoj, ohranjanje obstoječega poselitvenega vzorca, mešana raba prostora je torej tudi $z$ vidika prihodnje večje rabe endogenih naravnih (in drugih regionalnih virov) in upoštevanja nosilnosti okolja optimalna prostorska in regionalna usmeritev.

$\mathrm{Z}$ vidika vrednotenja endogenih naravnih virov tudi kot razvojnega regionalnega dejavnika naj bi bile do leta 2015 v ospredju naslednje sestavine okoljskega kapitala Slovenije (Plut in drugi, 2004):

1. različni vodni viri - vodo oskrbna, energetska in turistično-rekreacijska funkcija;

2. biomasa, zlasti lesna - industrijska, energetska in poselitvena funkcija;

3. geotermalna energija - energetska in turistično-zdravstvena funkcija;

4. zemljišča za pridobivanje biohrane - kmetijska, ekosistemska in poselitvena funkcija;

5. lignit - energetska funkcija;

6. naravne pokrajine - za rekreacijo in turizem na prostem (vključno s termalnimi zdravilišči);

7. biotska raznovrstnost - ekosistemska, kulturološka in rekreacijsko-turistična funkcija.

Sonaravno zasnovana raba obnovljivih virov energije naj bi imela prednost pred fosilnimi viri energije, potrebno jih je bolj velikopotezno vključevati v energetske zasnove regij, mest in lokalnih skupnosti (Strategija prostorskega razvoja Slovenije 2004). Višjo stopnjo regionalne oskrbe $\mathrm{z}$ obnovljivimi viri energije je potrebno povezati z varčevanjem energije, načini pospeševanja učinkovite rabe energije, sočasne proizvodnje toplote in električne energije ter tudi energetsko optimalnim regionalnim in lokalnim razmeščanjem poselitve in dejavnosti. Tudi raba obnovljivih virov prinaša določene negativne posledice v okolje, ki pa so manjše od npr. rabe fosilnih goriv. Zlasti v pokrajinsko občutljivih in zavarovanih območjih bo potrebna pretehtana, sonaravna raba obnovljivih naravnih virov. .Tako naj bi pretehtano povečanje količine in deleža obnovljivih domačih virov energije na račun zamenjave fosilnih goriv (ohranjanje omejene uporabe domačega lignita za soproizvodnjo električne energije in toplote) slonelo na: lesni biomasi (trajno sprejemljivo povečanje deleža poseka lesa ob upoštevanju prednostnih potreb lesne industrije), geotermalni energiji, hidroenergiji (okoljsko 
pretehtana gradnja HE v Spodnjem Posavju), tekoči biomasi (biodizel-oljna repica na omejenih površinah) in v primeru ekonomske in družbene sprejemljivosti na vetrni energiji, a zgolj na naravovarstveno in pejsažno sprejemljivih lokacijah.

V politični in strokovni javnosti se pogosto pojavlja vprašanje oziroma dilema: ali ne bo ambiciozno načrtovano varovanje narave v okviru zavarovanih območij in Nature 2000 na več kot tretjini državnega ozemlja omejilo ali pospešilo regionalni razvoj, okrepilo izseljevanje prebivalstva ter zaraščanje kulturne pokrajine. Ohranitev visoke stopnje biotske raznovrstnosti, torej rastlinskih in živalskih vrst, habitatnih tipov in ekosistemov na evropsko in planetarno nadpovprečnem deležu državnega ozemlja je namreč temeljni strateški cilj s področja varstva narave v Sloveniji. Delež zavarovanih območij (po kategorijah IUCN in drugih kategorijah zavarovanja ) je sicer leta 2003 znašal okoli $10 \%$, kar je bilo pod evropskim (nad $13 \%$ ) in svetovnim povprečjem (okoli $12 \%$ ). Predlog Nacionalnega programa varstva okolja (1999) za bistveno povečanje zavarovanih območij (zlasti krajinskih parkov) se do leta 2005 ni uresničil. Po predlaganih 286 lokacijah evropskega ekološkega ozemlja Natura 2000 na 35,5 \% ozemlja (kljub strokovno neupravičenemu izvzetju nekaterih lokacij v zadnji fazi) pa je Slovenija v vrhu držav EZ-25. Varstveni režim v območjih Natura 2000 je prilagojen ciljni vrsti (habitatu), medtem ko je npr. v rezervatih širše zasnovan. Seznami vrst in habitatov so nastali iz potreb ohranjanja redkih in ogroženih vrst/habitatov v drugačni zemljepisni širini. Vrste, ki so lokalno/regionalno ogrožene drugod v srednji ali severni Evropi, so v Sloveniji lahko pogoste in obratno. Območja Natura 2000 se nahajajo tudi v pokrajinah z intenzivno rabo, kjer bi rezervatov najbrž ne bilo mogoče vzpostaviti.

Brez dvoma pomeni primernost tretjine ozemlja Slovenije za uvrstitev v evropsko ekološko omrežje Natura 2000 med drugim tudi strateško pomembno spremembo pri načrtovanju prostorskega in regionalnega razvoja. Čeprav praviloma varovalni režimi Nature 2000 niso tako strogi pri omejevanju posegov v okolje kot to velja zavarovana območja IUCN (preveri), prinašajo $\mathrm{v}$ praksi okrepljeno varovalno funkcijo ter sonaravno poselitveno in gospodarsko usmeritev regionalnega razvoja. Zlasti regije oziroma lokalne skupnosti s velikim, celo prevladujočim ozemljem v okviru območij Nature 2000, se bodo v uvajalnem obdobju soočile s številnimi novimi prostorskimi in razvojno-varovalnimi dilemami ter problemi, ki bodo zahtevali dodatna, večja državna in evropska sredstva za ohranjanje območij visoke biotske raznovrstnosti. Izračuni so namreč pokazali, da so povprečni evropski stroški upravljanja v območjih Nature 2000 ocenjeni na 80 EUR/ha/leto, brez individualnih plačil kot so dokup zemlje ali plačila lastnikom (Stanovnik in Ekar Slabe, 2004, 53). V primeru, da bi bilo torej okoli 700000 ha ozemlja Slovenije uvrščeno v območje Natura 2000, naj bi torej po sedanjih evropskih izkušnjah letni stroški upravljanja znašali okoli 56 milijonov EUR oziroma več kot 13 milijard SIT. Glede na dejstvo, da je večina območij Nature 2000 v Sloveniji predvideno na gozdnih zemljiščih, naj bi bili stroški sicer manjši, vendar še vedno za državni proračun zelo veliki.

Razen določenih sredstev državnega proračuna bo potrebno uporabiti možnosti za izkoriščanje evropskih finančnih mehanizmov (LIVE III, Sklad za podporo razvoju podeželja, Leader+, INTERREG III; Sklad za evropski regionalni razvoj, Evropski socialni sklad in Kohezijski sklad) ter multirateralne finančne institucije (Svetovna banka, Evropska investicijska banka itd.). Zaradi dokaj realne možnosti zmanjšanja sredstev za regionalni razvoj 
v prihodnji finančni perspektivi EZ (2007-2013) bo potrebno vložiti veliko politične energije v pogajanja za pridobitev znatne potrebne finančne pomoči EZ za upravljanje obsežnega “evropskega" ekološkega omrežja na ozemlju naše države. Tudi zaradi predlaganega, evropsko bistveno nadpovprečnega deleža ozemlja Slovenije v območju Nature 2000 bo zlasti sonaravno gozdarstvo (ob kmetijstvu) postalo ključno za uspešno upravljanje. Pomembna strateška prednost Slovenije pri ohranjanju narave je dejstvo, da tradicionalno prevladujoče sonaravno gospodarjenje s slovenskimi gozdovi desetletja organsko povezuje ohranjanje narave in biotske raznovrstnosti ter gospodarsko dejavnost, pretehtana krepitev ekoloških in socialnih funkcij gozdov praviloma ne omejuje proizvodnje lesa. Sodimo, da je upravičeno in okoljsko sprejemljivo povečevanje lesne biomase v surovinski in energetski bilanci Slovenije (od $40 \%$ na okoli $60 \%$ letnega prirastka). Zlasti v vzpetem svetu pa bo gozdarstvo, posek lesa ostal eden izmed ključnih dejavnikov ohranjanja poseljenosti in skladnejšega, sonaravnega regionalnega razvoja.

\section{SKLADNEJŠI IN SONARAVNI REGIONALNI RAZVOJ (NAPREDEK) SLOVENIJE}

Slovenija lahko okoljevarstvene značilnosti in razsežnosti lastne in evropske prostorske in regionalne zasnove udejanja zlasti z zelo različni občutljivosti geografskega okolja trajno prilagojenim razmeščanjem temeljnih prostorskih in regionalnih struktur, ki so (poleg termoelektrarn) glavni viri okoljskih pritiskov: večja mesta in somestja, avtocestno omrežje in ravninska območja intenzivnega (kemiziranega) kmetijstva (Plut, 2002). Vendar gospodarski razvoj očitno delno poteka tudi na račun zmanjševanja regionalnega okoljskega kapitala, kar ponovno potrjuje nujnost uravnotežene krepitve vseh treh stebrov (gospodarskega, družbenega in okoljskega) trajnostno sonaravnega regionalnega razvoja, bolje napredka. Hkrati kljub formalno sprejeti evropski politiki policentričnega prostorskega in regionalnega razvoja je okoljevarstveno upravičena bojazen, da se bo prekomerno okrepila metropolizacija ljubljanske regije in litoralizacija Slovenske Istre, kar bi okrepilo že sicer pogosto prevelike okoljske pritiske v občutljivih pokrajinskih ekosistemih ter poglobilo razvojne medregionalne razlike. Tudi vse bolj očitno oblikovanje prebivalstveno in gospodarsko vitalnih območij ob avtocestnem omrežju in usihanje drugih območij krepi regionalne razlike in zgoščuje okoljske pritiske v nekaterih občutljivih pokrajinskih ekosistemih. Povečevanje medregionalnih razvojnih razlik sproža na osebnih vozilih zasnovano dnevno migracijo iz razvojno šibkih regij, kar bistveno krepi prometne pritiske, vključno z emisijami toplogrednega ogljikovega dioksida.

Pričakovano zmanjšanje skladov EZ (zlasti zaradi skromne gospodarske rasti) za podpore skladnejšemu regionalnemu razvoju v novih članicah ponovno prinaša potrebo večje finančne podpore $\mathrm{v}$ okviru državnega proračuna in sektorskih politikah. Upadanje števila prebivalstva $v$ mestih (začelo se je že $v$ drugi polovici 80. let) na račun nadpovprečne rasti $v$ obmestjih pa je že povezano $\mathrm{z}$ naraščanjem števila delovnih mest tudi v obmestjih, kar vodi $\mathrm{k}$ okoljsko pozitivnemu (npr. manjša poraba energije za prevoz, krepitev pokrajinske pestrosti) prostorskemu prepletanju funkcij v bivanja in dela (Ravbar, 2002). Kljub teoretičnim obetom 
tudi okrepljena terciarizacija slovenskih regij in hitrejše uveljavljanje informacijske družbe in tehnologij (̌se) ni povzročilo zmanjšanje snovno-energetskih tokov proizvodnje in potrošnje. Zato so ukrepi za zmanjševanje medregionalnih razlik v smeri krepitve policentričnega razvoja tudi okoljevarstveno praviloma sprejemljivi, saj v slovenskih razmerah prinašajo regionalno in lokalno večjo uravnoteženost med samočistilnimi zmogljivostmi ter manjšo zgoščenost pritiskov na okolje (Ravbar, Plut, 1999; Ravbar, 2003). Regionalna politika zmanjševanja gospodarskih in družbenih razlik in dviga materialnega blagostanja bi morala hkrati ohranjati zmogljivost opravljanja ekosistemskih storitev in ohranjanje biotske ter pokrajinske pestrosti. V regijah Slovenije so različni obnovljivi naravni viri, ki v primeru sonaravne rabe predstavljajo tudi trajen regionalni razvojni dejavnik.

Hkrati velja podčrtati, da tudi v Sloveniji in celotni EZ še ni prišlo do razdvojitve gospodarske rasti in večje porabe naravnih virov ter $\mathrm{s}$ tem povezanimi večjimi pritiski na planetarno, regionalno in lokalno okolje, prostor. Zgolj razpršeno zasnovani posamični ukrepi regionalno odgovornejšega ravnanja $\mathrm{z}$ naravnimi viri še niso prinesli splošnega zmanjševanja antropogenih snovno-energetskih in emisijskih tokov ob hkratnemu dvigu materialnega blagostanja, rasti BDP. Integracija ukrepov materializacije oziroma preprečevanja npr. nastajanja in recikliranja odpadkov, spodbujanje energetsko in surovinsko manj intenzivnih oblik proizvodnje, potrošenje, bivanja, prevoza in različnih novih tehnologij je v Sloveniji in $\mathrm{v}$ veliki meri tudi v EZ skromna, premalo spodbujana.

Ključni sonaravni regionalni izziv EZ in s tem tudi Slovenije je skladnejši regionalni razvoj in s tem povezano uravnavanje okoljskih pritiskov poselitve, gospodarstva, infrastrukture in pokrajinske rabe $\mathrm{v}$ okviru planetarne in različnih regionalnih ter lokalnih zmogljivosti okolja, njegovih sestavin. Kljub znatnim preteklim vlaganjem preko kohezijske politike $\mathrm{v}$ najmanj razvite evropske regije se regionalne razlike zelo počasi zmanjšujejo (Poročilo o razvoju, 2005). Po mnenju Evropske agencije za okolje naj bi prihodnje odločitve prostorskega in regionalnega načrtovanja EZ izhajale iz ekosistemskega pristopa, torej upoštevanja zmogljivosti specifičnih biofizikalnih in okoljskih virov, omejevanja materialnih tokov, ti. kritičnega naravnega kapitala (zrak-podnebne spremembe, vodni viri, biotska raznovrstnost) in nosilnosti okolja (Europe's Environment 2003, 281). Za Slovenijo je ključen prehod iz pretežno razpršenega oziroma razpršeno mozaičnega modela v mrežno mozaični, z usmerjanjem gradnje $v$ zaključena območja, disciplinirano rabo prostora in vsestranskim varovanjem okolja (Pogačnik 2000). Z vidika zahtev ti. močne regionalne sonaravnosti je zaželeno prilagajanje okoljskih pritiskov poselitve, zaposlitve, šolanja, nakupov, rekreacije regionalni in lokalni zmogljivosti okolja ter naravnih virov. To pomeni, da je za slovenske regije sonaravno optimalna zmerna, policentrično zasnovana zgostitev prebivalstva in dejavnosti (mešana raba prostora) v mozaičnem regionalnem vzorcu rabe prostora, mestni regiji, vključno z obsežnimi prednostnimi območji varovanja in ekološkimi koridorji. Z okoljskega vidika torej odsotnost obsežnih mestnih zgostitev predstavlja prednost, kritično regionalno razvojno maso pa je mogoče doseči v okviru omrežja povezanih mest oziroma somestij.

Reliefna razbitost ozemlja Slovenije in s tem povezane manjše samočistilne zmogljivosti dolin in kotlin se geografska okoljska determinanta (geografska stalnica), ki omejuje pretirano (metropolitansko) koncentracijo, a omogoča z vidika porabe naravnih virov (zlasti porabe prostora in energije) in s tem povezane manjše entropije njihove rabe priporočljivo »zmerno« 
koncentracijo prebivalcev in dejavnosti (Plut, 2002). V sonaravno prehodnem obdobju je tudi z vidika ohranjanja že zelo skrčenega obsega kulturne pokrajine primerno ohraniti in z državnimi sredstvi spodbujati določene prvine policentrično-hierarhičnega sistema centralnih naselij višje stopnje (npr. središč nacionalnega pomena) kot potreben nosilni regionalni gospodarski in oskrbni temelj sicer decentraliziranega oblikovanja mestnih regij. Umiritev suburbanizacije, ohranjanje tudi stanovanjske funkcije mestnega središča, umiritev cestnega in razvoj drugih oblik okolju prijaznejših prometa ter izboljšanje kakovosti bivalnega okolja so temeljne strateške sonaravne naloge politik slovenskih mest.

\section{SKLEP}

Slovenijo glede na velikost ozemlja označujejo relativno velike medregionalne razlike, višji materialni napredek pa je bil dosežen delno tudi na račun slabšanja kakovosti regionalnega in lokalnega okolja. V načrtovanju regionalne politike Slovenije se zelo postopoma uveljavljajo nekateri varovalno-razvojni strukturni regionalni premiki, kar kaže npr. postopna ekologizacija večjega števila industrijskih podjetij, večje podpore sonaravnemu razvoju kmetijstva, načrtovana večja regionalna raba obnovljivih naravnih virov in predlogi ekološkega omrežja Natura 2000. Zahteven prihodnji trajnostni sonaravni izziv Slovenije pa je konkretna in učinkovita integracija varstva okolja v sektorske politike, zlasti preko prostorskega načrtovanja in regionalnih razvojnih projektov (Stanovnik in Ekar Slabe, 2004). Regionalna in prostorska politika pa naj ob sonaravnemu načinu rabe endogenih virov okolja in potrebnih ukrepih za zmanjševanje medregionalnih razlik upoštevala tudi nujnost odprave starih okoljskih bremen in različne regionalne zmogljivosti geografskega okolja.

\section{Viri in literatura}

Černe, A., 2004: Dispersed and Decentralised Settlement System. V: Dela, 21, 83-96.

Europe's Environment: the Third Assessment. 2003. European Environment Agency, Copenhagen, 342 str.

Hočevar, M., 2005: Okoljevarstveni vidiki razvoja slovenskih industrijskih podjetij (magistrsko delo-osnutek). Oddelek za geografijo, Filozofska fakulteta, Ljubljana, 120 str.

Kušar, S., 2004: Cities of Slovenia Tomorrow According to Regional Development Plans. V: Dela, 21, 145-155.

Nacionalni program varstva okolja. 1999. MOP, Uprava RS za varstvo narave, Lj., 102 str.

Plut, D., 2002: Okoljevarstveni vidiki prostorskega razvoja Slovenije. Razprave Filozofske fakultete, Ljubljana, 292 str.

Plut, D., Kryštufek, B., Medved, S., Adamič, M., Lampič B., 2004: Vrednotenje vloge naravnih virov (okoljskega kapitala) Slovenije v Strategiji razvoja Slovenije z vidika konkurenčnosti in kakovosti življenja (raziskovalna naloga). Oddelek za geografijo FF, Ljubljana, 116 str.

Pogačnik, A., 2000: Urejanje prostora za tretje tisočletje. Študentska založba, Lj., 178 str. Poročilo o razvoju 2005. 2005: Urad za makroekonomske analize in razvoj, Ljubljana, 55 str. 
Resolucija o nacionalnem programu varstva okolja (predlog). 2005: Ministrstvo za okolje in prostor RS, Ljubljana, 150 str.

Ravbar, M., 2002: Sodobne težnje v razvoju prebivalstva in delovnih mest-pot k sonaravnemu in decentraliziranemu usmerjanju poselitve v Sloveniji. V: IB revija 2/2002 Ljubljana, $12-41$.

Ravbar, M., 2003: European Spatial Developmnet Documents - The Role and Challenges of the Implementaion of Polycentric Regional Development in Slovenia. V: IB revija, 2-3/2003, 20-30.

Ravbar, M., Plut, D., 1999: Prispevek k proučevanju regionalno-geografskih razsežnosti oblikovanja mestnih regij v Sloveniji v pogojih globalizacije in trajnostno sonaravnega razvoja. V: Dela, 14, 99-114.

Slovenski kmetijsko okoljski program (2001-2006). 2001: Ministrstvo za kmetijstvo, gozdarstvo in prehrano, Ljubljana, 72 str.

Stanovnik, P., Slabe Ekar, R., 2004: Znanost in raziskovanje za uravnoteženi razvoj. V: Zbirka Usklajeno in sonaravno11, Svet za varstvo okolja RS, Ljubljana, 51-54.

Strategija razvoja Slovenije (osnutek). 2004: Urad za makroekonomske analize in razvoj, Ljubljana, 98 str.

Strategija regionalnega razvoja. 2001: Ministrstvo za gospodarstvo, Ljubljana, 98 str.

Strategija prostorskega razvoja Slovenije. 2004. Ministrstvo za okolje, prostor in energijo, Ljubljana, 75 str.

Špes, M., 2000: Geografske značilnosti pokrajinsko ranljivih območij v Sloveniji. V: Geographica Slovenica 33/I, 9-46.

Vintar, K., 2003: Okoljevarstveni vidiki sonaravnega regionalnega razvoja Slovenije (magistrsko delo). Oddelek za geografijo, Filozofska fakulteta, Ljubljana, 179 str.

Vrišer, I., 1998: Gospodarska geografija. Geografija Slovenije, Slovenska matica, Ljubljana, $362-433$.

\section{SUSTAINABLE PLAN FOR REGIONAL DEVELOPMENT OF SLOVENIA}

\section{Summary}

Negative effects on the environment caused by the unbalanced regional development of Slovenia are a common landscape result of the excessive concentration of people and activities in the geographical areas of poor self-protective capacities. Also the ever more intense development of areas, vital in view of the population and economy, along the motorway network and the resulting decline of other areas further increase regional differences and cause the concentration of environmental impacts in certain sensitive landscape ecosystems. The data and various findings show that the economic growth in Slovenia as a whole and in its most developed region (central Slovenia) in particular was also reached at the cost of environment and exhausting its natural resources, unreasonable land use, high energy intensity 
and excessive growth of emission-intensive industries, intense use of chemicals in agriculture, and of other sector policies, mainly unsustainable. Slovenia is typical for high spatial dispersion of smaller settlements and numerous settlements of dispersed houses which further results in a more intensive use of natural resources in various areas and in increased transport.

The major sustainable regional challenge to the EU, and consequently also to Slovenia, is a more balanced regional development and the related balancing of environmental impacts of the settling, economy, infrastructure and landscape use within the scope of the planetary and various regional and local capacities of the environment. This means that sustainably optimal for Slovenian regions is a moderate, polycentrically distributed concentration of the population and activities (mixed land use) in the form of a mosaic-like regional pattern which also includes extensive nature-conservation areas and ecological corridors.

Measures necessary for reducing interregional differences in the sense of strengthening polycentric development are, as a rule, acceptable from the standpoint of environmental protection, because in the situation of Slovenia they bring, on both regional and local levels, a better balance of self-protective capacities and a lower concentration of impacts on the environment. The regional policy of reducing economic and social differences and rising the material welfare should concurrently maintain the capacity of performing the ecosystemic services and conserve the biotic and landscape diversities. In the regions of Slovenia there are different renewable natural resources which, in the case of a sustainable use, also represent a permanent regional factor of development.

Also in the planning of regional policy several sustainable structural regional shifts are slowly gaining ground, which is manifested, for example, by a gradual ecologization of a considerable number of industrial enterprises, a stronger support to sustainable development of agriculture, plans for a greater regional use of renewable natural resources and the proposals for the ecological network of the Natura 2000. The major future sustainable challenge to Slovenia is to effectively put in practice the integration of environmental protection into the policies of individual sectors, particularly through the spatial planning and regional development projects. 
